\title{
Space Superiority: A Call to Space Warriors
}

\author{
Cynthia A. S. McKinley \\ Major, United States Air Force \\ 150 Vandenberg Street, Suite 1105 \\ Peterson AFB, CO 80914-4610 \\ 719-554-9964 \\ cmckinle@spacecom.af.mil
}

Abstract-This essay ${ }^{1}$ discusses the importance of developing space superiority campaigns for future warfare success. It provides strategists with a coercion theorybased conceptual framework to provide a broader range of coercion mechanisms than has traditionally been offered. To selectively neutralize space systems, space strategists must move beyond the Cold War's spacecraft destruction-only focus and employ space superiority campaigns composed of a variety of active defensive and offensive counterspace operations mechanisms. The author encourages space strategists to develop space superiority campaigns to help America coerce future adversaries.

\section{TABLE OF CONTENTS}

1. INTRODUCTION

2. FULl CONFLICT SPECTRUM SPACE SUPERIORITY

3. HISTORICAL FOUNDATIONS AND EVOLUTION

4. CONSIDERATIONS FOR EXECUTING MILITARY SPACE SUPERIORITY CAMPAIGNS

5. CONCLUSION

\footnotetext{
1 This essay extracts a theme from the author's essay entitled Space Superiority: An Essential Contribution to the Terrestrial Warfighter. This December 1996 version updates the author's February 1996 manuscript.
}

\section{INTRODUCTION}

The very word superiority ${ }^{2}$ conjures up images of triumphant combatants racing unopposed across formerly contested land, sea or sky. It is a term which captures the essence of Americans' ultimate goal in any contest, be it military or other. Since the inception of the United States Air Force, the concept of superiority has driven much of airpower's force structure and personnel training; America has heavily invested in platforms and personnel which deliver air superiority during military operations.

The importance of air superiority is well understood by terrestrial warfighters; ${ }^{3}$ however, space superiority ${ }^{4}$ is a concept that is

\footnotetext{
${ }^{2}$ The definition used in this essay is that superiority is the state or quality of being greater in power.

${ }^{3}$ Terrestrial warfighters include land, sea, and air warriors. Space warfighters are those warriors involved with controlling the space, ground, or link elements of space systems. HQ USAF, Air Force Doctrine Document (AFDD) 4, Space Operations Doctrine, Draft December 15, 1995, 3.

4 Like air and maritime superiority, military space superiority is the space-related end-state sought by space warriors to help control the battlespace. Battlespace control is the degree of control necessary to employ, maneuver, and engage forces while denying the same capability to adversary forces. Battlespace control is one of two components of warfighting. The other component is shaping the battlespace. HQ
} 
seldom articulated and has benefits that escape widespread appreciation. The lack of understanding of or appreciation for space superiority may partially be attributed to the fact that as a space pioneer, America has enjoyed de facto space superiority since that became important. The number of nations possessing space systems has remained relatively small and America's military challengers have generally possessed limited space capabilities; however, a brief review of international space activities eliminates any misconception that space capabilities will be limited to a few nation-states.

By the turn of the century, military, civil and commercial exploitation of space will be an international norm. Some entities will likely have capabilities designed to challenge America's space superiority. Political and economic instruments of power or passive defensive counterspace ${ }^{5}$ military operations may not be sufficient coercion mechanisms to maintain peace in the new world order. To remain victorious in military operations, America must coerce its challengers by ensuring space superiority. American forces must be prepared to wage space superiority campaigns composed of active defensive ${ }^{6}$ and offensive ${ }^{7}$ counterspace operations. To help

USAF/XO, Global Reach - Global Power Expanded, Draft November 6, 1995, 9-11.

${ }^{5}$ Passive defensive counterspace (PDCS) operations preserve our ability to use friendly space systems. The objectives of passive defense are to reduce the vulnerabilities and to protect and increase the survivability of friendly forces and the information they provide. Ibid., 6-8.

${ }^{6}$ Active defensive counterspace (ADCS) operations reduce or preclude the effectiveness of an adversary's counterspace operations. The objectives of active defense are to detect, track, identify, intercept, and destroy or neutralize adversary space and missile forces. Ibid.

${ }^{7}$ Offensive counterspace (OCS) operations destroy or neutralize an adversary's space systems or the information they provide through attacks on the various warfighters understand the challenge of America's space superiority future, this essay discusses the full conflict spectrum framework for attaining space superiority, highlights some of its historical foundations and evolution, and concludes with some considerations for executing military space superiority campaigns.

\section{FULL CONFLICT SPECTRUM SPACE SUPERIORITY}

Full conflict spectrum space superiority includes all efforts to ensure America's space superiority during peace, crisis or war. It has political, economic and military components and results in successful coercion by influencing, ${ }^{8}$ deterring, ${ }^{9}$ compelling ${ }^{10}$ or defeating ${ }^{11}$ adversaries. Full conflict spectrum space superiority requires America's military space forces to maintain capabilities to protect American space assets; to influence allies, friends, rogues or peers; and to deter, compel or defeat rogues and peers. Influencing and deterring imply coercion without force; compelling and defeating imply the use of force. The figure below depicts the coercion spectrum in which space superiority functions.

elements of space systems. The four major purposes of OCS operations are to disrupt, deny, degrade, or destroy space assets or capabilities. Ibid.

${ }^{8}$ To influence is the power to affect others, seen only in its effect. It is the power to produce effects without exerting physical force or authority. Jean $L$. McKechnie, Webster's New Twentieth Century Dictionary of the English Language (New York: Simon and Schuster, 1983).

${ }^{9}$ To deter is to discourage or keep an entity from action through fear, anxiety, or doubt. Ibid.

${ }_{10}$ To compel is to drive or urge with force; to necessitate by physical or moral force; to take by force or violence; to cause to yield. Ibid.

${ }^{11}$ To defeat is to overcome or vanquish; to beat; to overthrow. Ibid. 


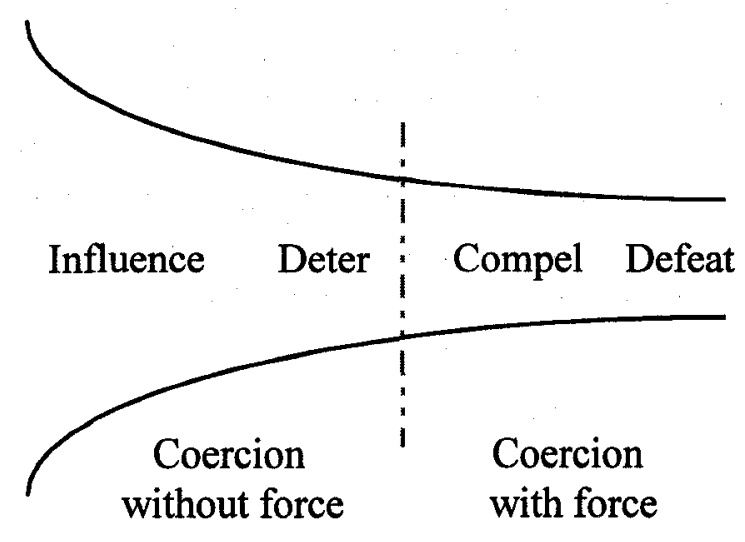

Figure. The Coercion Spectrum
Although the lines between influencing, deterring, compelling and defeating adversaries often blur, analysis of these objectives and the various mechanisms associated with them indicates that political, economic and passive defensive counterspace operations may best be employed to influence; political, economic and active defensive counterspace operations may be used to deter; and active defensive and offensive counterspace operations may be used to compel or defeat. The basis for these analytical associations is delineated and expanded upon in the table below. 
Table. Full Conflict Spectrum Space Superiority

\begin{tabular}{|c|c|c|c|}
\hline \multicolumn{2}{|c|}{ Coercion } & \multirow[b]{2}{*}{ Type of Activity } & \multirow[b]{2}{*}{ Mechanisms } \\
\hline Objective & Sub-Objective & & \\
\hline \multirow[t]{12}{*}{ Influence } & $\begin{array}{l}\text { Limit accessibility } \\
\text { or availability }\end{array}$ & Political / Military & Cooperative agreements; arms control initiatives \\
\hline & \multirow[t]{3}{*}{ Limit capabilities } & \multirow[t]{2}{*}{ Political / Military } & Terminate selected military sales \\
\hline & & & Disrupt technology transfers \\
\hline & & PDCS & $\begin{array}{l}\text { Change spacecraft operations modes } \\
\text { (e.g., selective availability) }\end{array}$ \\
\hline & \multirow[t]{7}{*}{ Protect systems } & \multirow[t]{6}{*}{ PDCS } & $\begin{array}{l}\text { Develop / deploy non-jammable encrypted } \\
\text { connectivity links }\end{array}$ \\
\hline & & & Deploy survivable / maneuverable spacecraft \\
\hline & & & Deploy / activate on-orbit spares \\
\hline & & & Deploy decoys \\
\hline & & & Conceal space assets \& nodes \\
\hline & & & $\begin{array}{l}\text { Deploy mobile back-up systems to proliferate up \& } \\
\text { down links }\end{array}$ \\
\hline & & ADCS & Deploy threat detection \& identification systems \\
\hline & Discourage aggression & ADCS & $\begin{array}{l}\text { Reposition on-orbit spacecraft for improved } \\
\text { observation }\end{array}$ \\
\hline \multirow[t]{5}{*}{ Deter } & Demonstrate resolve & Political / Military & Embargo or sanction weapons systems \\
\hline & Protect systems & Political / Military & Declare or enforce neutrality laws \\
\hline & Identify limits & Political / Military & Declare war zones \\
\hline & \multirow[t]{2}{*}{ Discourage aggression } & \multirow[t]{2}{*}{ ADCS } & Raise space force readiness posture \\
\hline & & & Deploy / activate ASAT systems \\
\hline \multirow[t]{8}{*}{ Compel } & \multirow[t]{3}{*}{ Reduce capabilities } & \multirow[t]{3}{*}{ ADCS } & $\begin{array}{l}\text { Demonstrate limited space options on spacecraft / } \\
\text { ground nodes }\end{array}$ \\
\hline & & & $\begin{array}{l}\text { Damage / destroy mobile surveillance / tracking } \\
\text { systems }\end{array}$ \\
\hline & & & Disrupt adversary counterspace sensors, C4 links \\
\hline & Eliminate threat & ADCS & Destroy ASATs \\
\hline & \multirow[t]{4}{*}{ Reduce capabilities } & \multirow[t]{4}{*}{ OCS } & $\begin{array}{l}\text { Attack ground-based space nodes' electrical power } \\
\text { linkages }\end{array}$ \\
\hline & & & $\begin{array}{l}\text { Employ non-lethal weapons (e.g., electronic } \\
\text { warfare) against space, ground or link element } \\
\text { software or electronics }\end{array}$ \\
\hline & & & Jam satellite up or down links \\
\hline & & & Disrupt spacecraft sensors \\
\hline \multirow[t]{5}{*}{ Defeat } & \multirow[t]{5}{*}{ Eliminate capabilities } & ADCS & Attack fixed surveillance / tracking systems \\
\hline & & \multirow[t]{4}{*}{ OCS } & Attack site facilities \\
\hline & & & Attack spacecraft storage or fabrication facilities \\
\hline & & & Attack space systems headquarters or spaceport \\
\hline & & & Attack spacecraft \\
\hline
\end{tabular}


America's ability to influence and deter through the use of coercive mechanisms for space systems is fairly well understood by America's political and military leaders. Thus far, America's coercive activities have revolved around political, economic and passive defensive counterspace operations. Political and military leaders have long pursued measures that limit adversary capabilities, protect space systems, demonstrate resolve and discourage aggression. Beyond these measures, strategic space theory has narrowly focused on mechanisms to coerce a solitary peer competitor. The unique circumstances of the Cold War superpower stand-off often limited strategic space theory to singular solutions for achieving space superiority during conflict. As will be discussed in the next section, this narrow focus has left the compellence and defeat mechanisms largely unexploited. This presents America's military space forces with opportunities and challenges as they attempt to achieve space superiority in the new world order. Like land, sea and air warfare strategists who rely upon an extensive variety of compellence and defeat mechanisms to attain victory in battle, space strategists must plan to exploit these mechanisms for the military's future space superiority campaigns.

\section{HISTORICAL FOUNDATIONS AND EVOLUTION}

When attempting to illuminate space superiority's history and evolution, it is important to review two of the primary factors which have shaped the concept. Those factors are the historical solutions for obtaining space superiority and the current and future environment in which space superiority must be achieved.

Throughout the Cold War, American leaders set the tone for American spacepower development through executive guidance which revolved around space protection, reaction and destruction. This defensive posture set the tone for American space power development. The military began developing an active defensive counterspace weapon designed to accomplish the same objective as that of most mid-twentieth century terrestrial warfare weapons: physically destroy the offensive systems threatening friendly space assets or providing advantage to the adversary. By 1959, America had tested the world's first anti-satellite weapon. Throughout the Cold War and even into the 1990 s, many leaders held on to their only active defensive counterspace weapon and its related concepts by endorsing antisatellite development as a primary objective of space research, development, testing and operations. ${ }^{12}$ During this formative period, military space theory did not evolve to include space superiority campaigns designed around a variety of active defensive and offensive counterspace operations. Many expressed the belief that America's solitary active defensive counterspace weapon would enable control of outer space. Military strategists of this era continued to apply terrestrial warfighting concepts to outer space without realizing that outer space and the objectives of space warfare may prove to be uniquely different.

When America entered the Persian Gulf War in 1991, antisatellite proponents actively reinforced this mind-set ${ }^{13}$ and many in today's military retain the same belief. While antisatellite weapons designed to destroy spacecraft may have been an important Cold War capability, they are insufficient for warfighting in today's increasingly complex space environment. The ongoing rapid commercialization of space is changing the

\footnotetext{
${ }^{12}$ For example, see General John L. Piotrowski, "Why the U.S. Needs an Antisatellite," National Befense, February 1990, 36-39.

13 Vincent Kiernan, "War Boosts Anti-Satellite Weapons Proponents," Space News, May 6-12, 1991, 7.
} 
potential combat environment from a military domain to an internationally intertwined commercial domain. Unlike tanks, ships, or aircraft, space systems may not have a sole owner. Some spacecraft serve as many as 135 consortium members. Some members may be friends and allies; some may be adversaries. During conflict, America's military forces must be prepared to employ international assets while simultaneously denying them to belligerents. This unique environment requires America's military space forces to possess the capability to maintain an exacting space order of battle ${ }^{14}$ and a wide variety of capabilities to deceive, disrupt, deny, degrade or destroy an adversary's ground, space or link elements.

To selectively neutralize offensive portions of space systems, space strategists need to move beyond the Cold War's spacecraft destructiononly focus and develop space superiority campaigns composed of active defensive and offensive counterspace operations mechanisms. This broader range of tasks recognizes that the military's responsibility to control space is not to control the medium but rather to control the adversary's ability to exploit and derive benefit from the medium and perhaps ultimately, to control the information the adversary receives from space assets.

\section{CONSIDERATIONS FOR EXECUTING MILITARY SPACE SUPERIORITY CAMPAIGNS}

Developing aggressive space superiority campaigns involves expanding upon and creatively employing compellence and defeat mechanisms similar to those previously identified. Some issues strategists should ponder when developing space superiority campaigns include considerations about the

\footnotetext{
${ }^{14}$ An exacting space order of battle includes orbital parameters and spacecraft information such as ownership, purpose, characteristics and capabilities.
}

goals and objectives of the adversary and of America. They should also have systemic space system data, political and military guidance and support force requirements.

The strategist's first task is to attempt to unravel the peer or rogue competitor's long and short term objectives and to determine how space assets contribute to the adversary's achievement of those objectives. The adversary may be using space-derived information to enable a preemptive attack against a neighboring nation. Perhaps use of the space assets enables some other form of political, economic or military adventurism.

The second task is to address what coercive objective the impending space superiority campaign seeks for the benefit of America. While recognizing that the lines between coercion objectives blur and that adversaries may not react as desired, the table presented earlier provides a starting point from which to begin devising a campaign. One fact to note when considering which mechanisms to employ is that one is not necessarily required to use the coercion spectrum in any given order. One may not necessarily begin with influence mechanisms and eventually move to defeat mechanisms. Rather, the strategist should consider the effect being sought ${ }^{15}$ then choose the mechanisms likely to achieve that objective. To ensure optimal courses of action, one must consider all mechanisms that may contribute to achieving the desired effect. Sub-objectives of a military space superiority campaign may include reducing an adversary's space capabilities, creating battlespace confusion, eliminating certain military-related space capabilities or other similar sub-objectives.

\footnotetext{
${ }^{15}$ The effect being sought is the coercive objective, for example, to influence, deter, compel or defeat.
} 
With insight on the adversary's possible goals and objectives as well as those of the United States, the strategist must gather the systemic information required to execute the campaign. Friendly forces may need ground, on-orbit, link and operational employment information. Ground information includes ground reception and control station locations, existence and locations of mobile ground reception or control facilities and ground station vulnerabilities. $^{16} \quad$ On-orbit information includes data such as an ephemeris, subsystem vulnerabilities, maneuver capabilities, sensor configurations and periods of natural disruption. ${ }^{17}$ Link information includes data on the number of up and down links and their frequencies, anti-jamming and encryption capabilities. Operational employment information includes comprehensive assessments on who uses the system, how it is employed, the system's contribution to the adversary's military strategy and system reconstitution capabilities to include the existence of ground, link or on-orbit sparing and periods of critical commanding.

Other important considerations prior to requesting support forces are identified limitations and the rules of engagement. Political and military guidance must be clearly identified prior to recommending to employ space superiority courses of action. This guidance is critical because, for example, the space strategist may devise a space superiority campaign which includes a militarily feasible plan to deny commercial photoreconnaissance data only to find that political restrictions disallow such actions.

Finally, the commander of space forces may need support from various ground, sea, air and

16 For example, locations of power sources, ground security personnel status, and physical security barriers.

17 Periods of natural disruption would include, for example, known times for solar interference, satellite eclipse, or proximity operations. space forces to execute the space superiority campaign. For synergistic battlespace effects, space superiority targeting must be integrated into the campaign planning and execution tools used by all applicable forces.

\section{CONCLUSION}

The considerations outlined above only hint at the comprehensive space superiority campaign plans which need to emerge from the military space community. The considerations are offered as points of departure for strategists interested in developing space superiority campaigns which look beyond the solitary solutions offered throughout the Cold War and which linger in the minds of many yet today.

During the Cold War, America focused its campaign plans on a sole peer competitor. There was a known adversary with known military capabilities. Outer space was nearly exclusively populated by military spacecraft. The adversary's ground and link elements were essentially inaccessible and America developed a solitary solution to eliminate threats. These conditions apply to only one portion of today's new world order. In the contemporary space environment, America must prepare itself to face a variety of rogue challengers and perhaps some time in the future, the reemergence of a peer competitor. Outer space is being exploited by potential adversaries who gain benefit from space assets owned by commercial consortia. Unlike the Cold War era, a future adversary's space system ground and link elements may be accessible yet mobile and difficult to target. While these facts create a challenging battlespace, they also offer opportunities for space warriors. Peacetime years are the ideal time to expand military concepts. These final years before we enter the twenty-first century beckon space strategists to expand our military space force contributions to national security by encouraging the development of space 
superiority campaigns designed to help America coerce rogue or peer competitors.

\section{REFERENCES}

[1] The Aspen Strategy Group, Anti-Satellite Weapons and U.S. Military Space Policy, Lanham, MD: University Press of America. 1986.

[2] Peter B. DeSelding and Andrew Lawler, "SPOT Halts Sales of Gulf Area Imagery," Space News, August 13-19, 1990.

[3] Gerhard von Glahn, Law Among Nations: An Introduction to Public International Law, London: Macmillan Publishing Company, 1981.

[4] Vincent Kiernan, "War Boosts Anti-Satellite Weapons Proponents," Space News, May 6-12, 1991.

[5] Jean L. McKechnie, Webster's Twentieth Century Dictionary of the English Language, New York: Simon and Schuster, 1983.

[6] General John L. Piotrowski, "A Joint Effort," U.S. Naval Institute Proceedings, February 1990.

[7] General John L. Piotrowski, "Why the U.S. Needs an Antisatellite," National Defense, February 1990.

[8] Paul B. Stares, "Deja vu: The ASAT Debate in Historical Context," Arms Control Today, December 1983.

[9] Paul B. Stares, The Militarization of Space: U.S. Policy 1945-1984, New York: Cornell University Press, 1985.

[10] Allen Thompson, "Space Reconnaissance Vulnerability," Space News, October 10-16, 1994.

[11] HQ USAF, Air Force Doctrine Document 4, Space Operations Doctrine, Draft December 15, 1995.

[12] HQ USAF, Air Force Manual 1-6, Military Space Doctrine, October 15, 1982.
[13] HQ USAF/XO, Global Reach-Global Power Expanded, Draft November 6, 1995.

[14] Steve Weber, "ASAT Proponents Fail to Reverse White House Policy," Space News, September 19-25, 1994.

[15] Andrew Wilson, Jane's Space Directory, 19941995, Great Britain: Biddles, Ltd, Guildford, and King's Lynn, 1994.

Cynthia A. S. McKinley is a strategy and policy analyst for Air Force Space Command. She has been in the space business for 15 years. Her space experience includes space systems orbital analyst, orbital analyst leader, tracking and impact prediction officer, launch processing officer, Space Shuttle operations officer, space systems deputy director, space systems senior director, chief of operations training, antisatellite command and control evaluator, Space Defense Operations Center $4 C$ command manager, chief of orbital analysis training, Cobra Dane system modernization command manager, and deep space surveillance site commander. She also has two years of experience with air and space intelligence warning operations through her position as an intelligence watch center commander. Major McKinley has served at Cheyenne Mountain and Peterson Air Force Bases, Colorado; Kapaun Air Station, Federal Republic of Germany; and Diego Garcia, British Indian Ocean Territories. She holds a bachelor's degree in mathematics and philosophy, a master's degree in international relations, and a master's degree in airpower art and science. Major McKinley is a graduate of Squadron Officer School, Air Command and Staff College, and the School of Advanced Airpower Studies. 